\title{
Manufacture technology of tofu shake added with red rice
}

\author{
Eun-Jeong Cho*, Sang-Soo Lee, Dong-Jin Kwon \\ Department of Food Processing and Distribution, Gangneung-Wonju National University, Gangneung 25457, Korea
}

\section{홍국쌀을 첨가한 두부 셰이크의 제조기술}

\author{
조은정* · 이상수 · 권동진 \\ 강릉원주대학교 식품가공유통학과
}

\begin{abstract}
To establish manufacturing technology of tofu shake added with red rice prepared with Monascus purpureus KCCM 60570, the quality characteristics of tofu shake added with M. purpureus KCCM 60570 were investigated. Also, we determined the optimal mixing ratios of raw materials including red rice for manufacturing tofu shake. Monacolin $\mathrm{K}$ and mold number of red rice were increased rapidly until $8^{\text {th }}$ day of incubation and then gradually increased during the 12 day manufacturing period. As the results, it was considered to be most suitable to prepare red rice

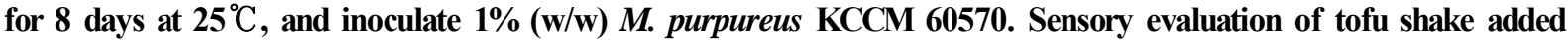
with red rice and tofu shake without red rice was not significantly different at $p<0.05$. In sensory evaluation, tofu shake added with $0.5 \%(\mathrm{w} / \mathrm{w})$ red rice was higher in taste, texture, and overall acceptability than the other. Therefore, the optimal mixing ratio of red rice and tofu shake is $0.5 \%(w / w)$. These results suggest that the addition of red rice could improve the quality of tofu shake.
\end{abstract}

Key words : red rice, Monascus purpureus, tofu shake, sensory evaluation, mixing ratio

\section{서 론}

홍국은 쌀에 Monascus속 곰팡이를 증식시켜 제조한 붉 은색의 쌀로 red koji 또는 Hong $Q u$ 으로 불리며(1), 중국에 서 수세기동안 식품뿐만 아니라 술을 비롯한 발효식품 제조 에 향미 증진제와 착색제로 사용해 왔고, 소화촉진과 혈액 순환 개선에도 효과가 있는 것으로 알려져 있다(2). 또한 dimerumic acid와 3-hydroxy-4-methoxybenzoic acid 등의 물 질에 의한 항산화작용도 우수한 것으로 보고되고 있으며 $(3,4)$, 혈압강하 작용으로 알려진 $\gamma$-aminobutyric acid와 콜 레스테롤 저하작용을 하는 monacolin-K(5-8) 등 효능이 입 증되어 2005년 식품의약품안전처는 홍국쌀을 혈중 콜레스 테롤의 개선에 도움을 주는 기능성 원료로 지정하였다.

*Corresponding author. E-mail : milkiforever@daum.net Phone : 82-33-650-3383, Fax : 82-33-648-2162

Received 3 November 2017; Revised 20 November 2017; Accepted 23 November 2017.

Copyright (c) The Korean Society of Food Preservation. All rights reserved.
국내에서 음료의 한 형태로 많이 섭취되고 있는 셰이크 (shake)는 우유, 초콜릿 등을 첨가하여 제조하며, 가장 대표 적인 밀크셰이크(milk shake)는 우유와 아이스크림, 또는 얼린 우유로 만든 차갑고 달콤한 음식이다. 맛을 내기 위해 각종 향료를 첨가하거나 바닐라, 초콜릿, 딸기 및 바나나 등을 곁들인 경우도 있으며, 휩트 크림(whipped cream)을 사용하는 경우도 있다(9). 셰이크는 일반적으로 후식으로 섭취하는 경우가 많지만 근래 바쁜 현대인의 식생활 패턴의 변화로 식사대용으로 섭취가 증가하는 추세이다.

현재 국내에서 시판하고 있는 셰이크는 검은 깨 엑기스 를 첨가한 두부 셰이크로 유일하게 국내에서 생산하고 있는 제품으로 나홀로족과 고령화 시대의 흐름에 맞추어 간편식 식사대용으로 소비되고 있지만 최근 국민들의 건강에 대한 관심이 높아지면서 식사대용으로 섭취하는 셰이크에 다양 한 기능성을 요구하고 있어 새로운 형태의 셰이크 개발을 필요로 하고 있다. 그러나 두부 셰이크에 대한 연구는 전무 하며, 특히 두부 셰이크의 품질 개선과 품목 다양화를 위한 기초자료가 미흡한 실정이다. 다만 $\operatorname{Kim}(10)$ 은 홍국쌀을 첨 가한 소시지의 품질을 분석하였고, Kwon(11)은 Monascus 
purpureus로 제조한 홍국쌀 추출물의 항산화성에 대한 기 능성을 조사하였다. 또한 Kim과 Lee(12)는 유통 중인 홍국 쌀의 에탄올 추출물을 diacylglycerol에 첨가하여 제조한 기능성 식용유의 기능성과 이화학적 특성을 분석한 연구 등이 있으나 두부 셰이크의 품질 개선에 관한 연구는 전무 한 실정이다.

따라서 본 연구에서는 기존의 검은 깨 엑기스를 첨가한 두부 셰이크의 원료 일부를 홍국쌀로 대체한 홍국쌀 첨가 두부 셰이크를 제조하여 제품의 개발 가능성을 알아보고 이의 제조기술에 대한 기초자료를 제공하고자 한다.

\section{재료 및 방법}

\section{실험재료}

본 실험에 사용된 홍국쌀, 현미, 백미는 2014년 강릉시 소재 마트 및 시장에서 구입하여 사용하였고, 두부 셰이크 제조에 필요한 전두부, 우유, 검은 깨 페이스트, 연유, 설탕 시럽 및 식염은 시중의 마트 및 전문점에서 구입하여 사용 하였다.

\section{홍국쌀의 제조}

홍국쌀은 한국미생물보존센터에서 분양받은 Monascus purpureus $\mathrm{KCCM}$ 60570으로 제조하였다. 즉 M. purpureus $\mathrm{KCCM} 60570$ 을 배양시킨 배양액을 찐 쌀에 $1 \%(\mathrm{w} / \mathrm{w})$ 를 접종 후 $25^{\circ} \mathrm{C}$ 항온항습기(TH-GA-300, JEIO TECH, Seoul, Korea)에서 12 일간 배양하면서 1 일마다 시료를 채취하여 수분, 붉은 색소인 monacolin $\mathrm{K}$ 및 곰팡이수를 측정하여 홍국쌀의 최적 제조기간을 결정하였다.

\section{홍국쌀 첨가 두부 셰이크의 제조}

M. purpureus $\mathrm{KCCM} 60570$ 으로 $25^{\circ} \mathrm{C}$ 에서 8 일간 제조한 홍국쌀을 기존의 두부 셰이크에 Fig. 1과 같이 혼합하여 제조하였다. 즉 기존 검은 깨 엑기스를 첨가한 두부 셰이크 제조에 이용되는 전두부, 우유, 검은 깨 페이스트, 연유, 설탕시럽, 식염 외에 본 연구에서 제조한 홍국쌀을 곱게 갈아 전두부의 일부로 대체하여 혼합한 것을 $92^{\circ} \mathrm{C}$ 에서 75 분 간 열처리한 후 냉각하였다. 이때 홍국쌀은 Table 1 과 같은 비율로 혼합하였으며 홍국쌀의 최적 배합비를 결정하기 위해 홍국쌀을 $0.3,0.5,0.7$ 및 $1.0 \%(\mathrm{w} / \mathrm{w})$ 로 달리하여 두부 셰이크를 제조하였다.

\section{시험방법}

수분은 $105^{\circ} \mathrm{C}$ 상압건조법(13)으로 하였으며, 환원당은 Somogyi법(14)에 준하였고 총당은 염산으로 분해한 후 Somogyi법(14)에 따라 분석하였으며 조회분은 $\mathrm{AOAC}$ 의 방 법(15)에 따라 행하였다. 조단백질은 Kjeldahl method(16)에
준하였으며 조지방은 Soxhlet 추출방법(17)을 이용하여 분 석하였다. M. purpureus KCCM 60570가 생성하는 monacolin $\mathrm{K}$ 는 Jung 등(18)의 방법에 준하여 추출한 다음 Absorbance microplate reader(Morecular Devices, CA, USA)를 이용하여 $512 \mathrm{~nm}$ 에서 흡광도를 측정하였다. 색도는 색차계(colorimeter, CM-3500d, Minolta, Tokyo, Japan)을 이용하여 L, a, b 값을 구하였다(19). 곰팡이수는 potato dextrose agar(Difco. Co.)(20), 세균수는 plate count agar(Difco. Co.)(20)를 사용 하여 계수하였으며, 대장균은 petri film을 이용하고 대장균 군은 MPN 방법(21)에 준하였다.

Table 1. The mixture ratio of raw materials for manufacturing of tofu shake added with red rice with Monascus purpureus KCCM 60570

\begin{tabular}{cccccc} 
& \multicolumn{4}{c}{ Sample } \\
\hline \multirow{2}{*}{ Parameters } & $\begin{array}{c}\text { Control } \\
\text { (tofu shake) }\end{array}$ & \multicolumn{3}{c}{ Tofu shake added with red rice } \\
\cline { 2 - 6 } & A & B & C & D \\
\hline Whole soybean curd & 48.7 & 48.4 & 48.2 & 48.0 & 47.7 \\
Milk & 44.8 & 44.8 & 44.8 & 44.8 & 44.8 \\
Black sesame paste & 1.0 & 1.0 & 1.0 & 1.0 & 1.0 \\
Condensed milk & 1.0 & 1.0 & 1.0 & 1.0 & 1.0 \\
Salt & 0.1 & 0.1 & 0.1 & 0.1 & 0.1 \\
Sugar syrup & 4.4 & 4.4 & 4.4 & 4.4 & 4.4 \\
Red rice ${ }^{1)}$ & - & 0.3 & 0.5 & 0.7 & 1.0 \\
\hline Total & 100 & 100 & 100 & 100 & 100 \\
\hline
\end{tabular}

${ }^{1)}$ Red rice was manufactured with Monascus purpureus KCCM 60570 at $25^{\circ} \mathrm{C}$ for 8 days.

관능검사

홍국쌀 첨가 두부셰이크의 관능검사는 강릉원주대학교 식품가공유통학과 학생 30명을 선발하여 실험목적과 방법 에 대하여 충분히 내용을 숙지 및 훈련을 시킨 후 실시하였 다. 평가항목은 맛(taste), 향(flavor), 색(color), 조직감 (texture), 전체적인 기호도(overall acceptability)를 9점 기호 척도법(1점: 매우 나쁘다, 9점: 매우 좋다)으로 평가하였다. 본 관능검사 연구계획서는 강릉원주대학교 2017년도 제6 차 기관생명윤리위원회(IRB) 심의를 통과하였다(승인번 호: GWNUIRB-2017-16).

\section{통계처리}

모든 실험은 3회 반복으로 행하였으며, 자료의 통계처리 는 Statistical Package for the Social Sciences(version 12.0, SPSS Inc., Chicago, IL, USA)를 이용하여 분산분석 (ANOVA)을 실시하였으며, 실험군 간의 유의성은 Duncan's multiple range test에 의하여 $\mathrm{p}<0.05$ 수준에서 비교하였다. 


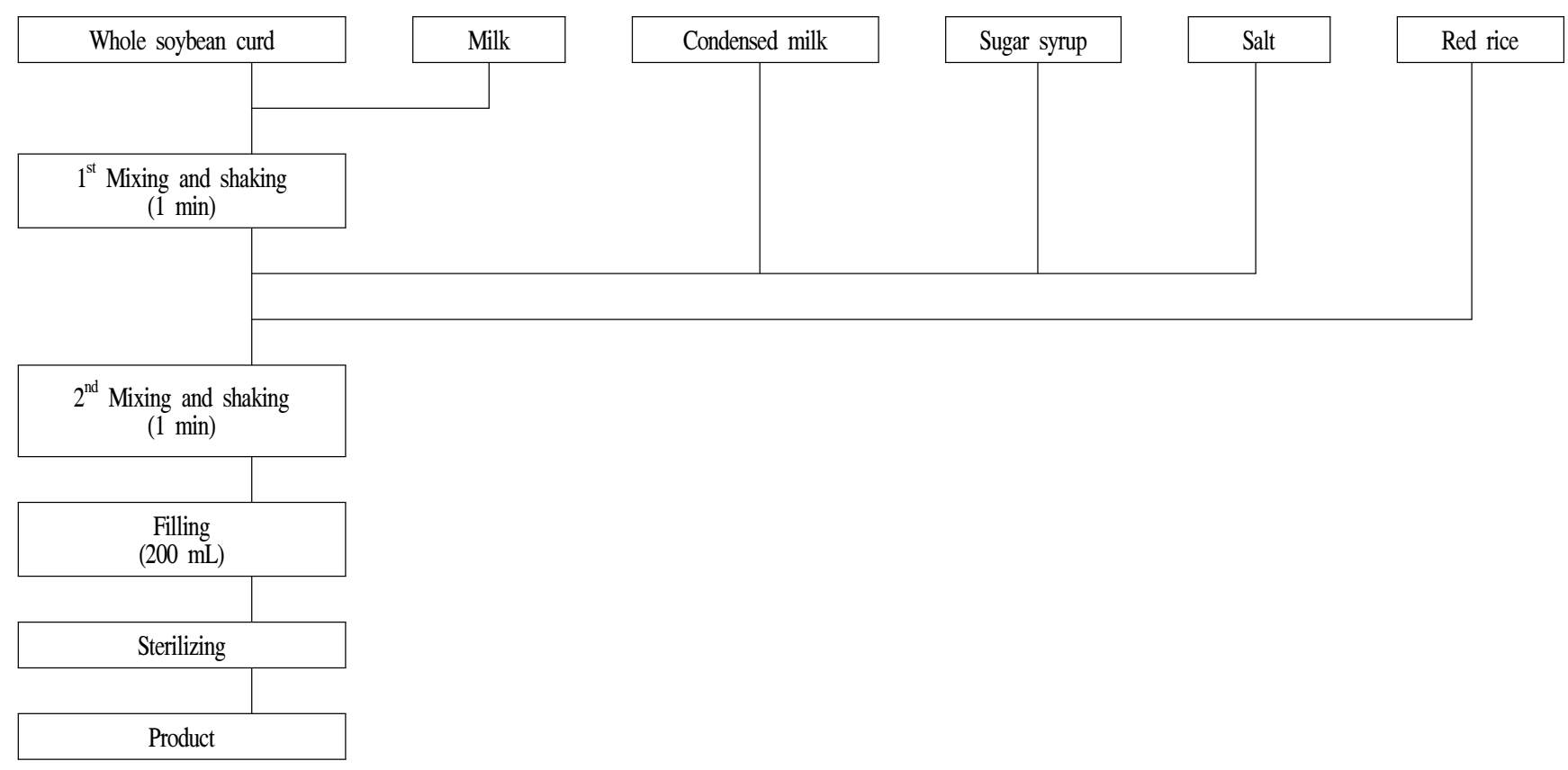

Fig. 1. Manufacturing procedure of tofu shake with red rice prepared with Monascus purpureus KCCM 60570.

\section{결과 및 고찰}

수분, monacolin $\mathrm{K}$, 곰팡이 함량 측정

백미밥에 $1 \%(\mathrm{w} / \mathrm{w})$ 의 M. purpureus KCCM 60570을 접종 한 후 $25^{\circ} \mathrm{C}$ 항온항습기에서 12 일간 배양하면서 1 일마다 시료를 채취하여 수분을 측정한 결과는 Fig. 2 와 같다. 홍국 쌀 제조기간 중 수분은 홍국쌀을 제조하는 12 일 동안 약간 씩 감소하는 경향을 보이고 있으며, 홍국쌀 제조 초기에는 $56.14 \%(\mathrm{w} / \mathrm{w})$ 에서 제조 12 일경에는 $53.11 \%(\mathrm{w} / \mathrm{w})$ 로 약간 감소하는 경향을 보이고 있었으나 유의할만한 큰 차이는 볼 수 없었다.

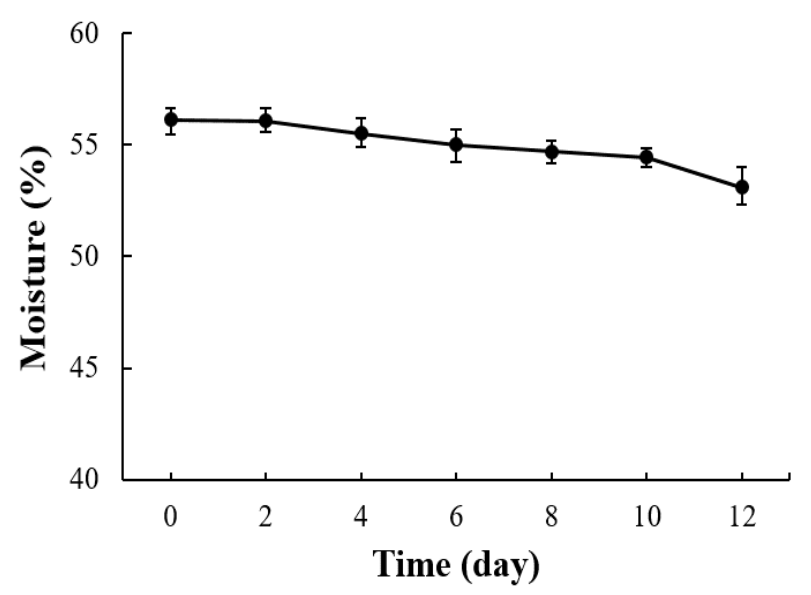

Fig. 2. Changes in moisture during manufacturing of red rice with Monascus purpureus KCCM 60570 at $25^{\circ} \mathrm{C}$ for 12 days.
M. purpureus $\mathrm{KCCM} 60570$ 로 홍국쌀을 제조할 때 생성 되는 붉은 색소인 monacolin $\mathrm{K}$ 를 추출하여 숙성기간별 생 성량을 흡광도로 나타낸 결과는 Fig. 3 과 같다. 홍국쌀 제조 초기에는 붉은 색을 볼 수 없었으나 1 일이 지나면서 약간 붉은 색을 띠기 시작하여 2 일 차는 흡광도가 $0.89,8$ 일차는 흡광도가 3.25 로 급격히 붉은 색소의 양이 증가한 이후 완만 히 증가하면서 12일 차는 흡광도가 3.72로 M. purpureus $\mathrm{KCCM}$ 60570에 의해 생성되는 붉은 색소는 제조한 지 8일 정도 지나면 충분한 색을 얻을 수 있는 것으로 확인되었다. monacolin K는 Monascus속의 붉은 곰팡이에 의해 생성된 것으로 cholesterol 생합성 저해물질이라는 것으로 밝혀졌

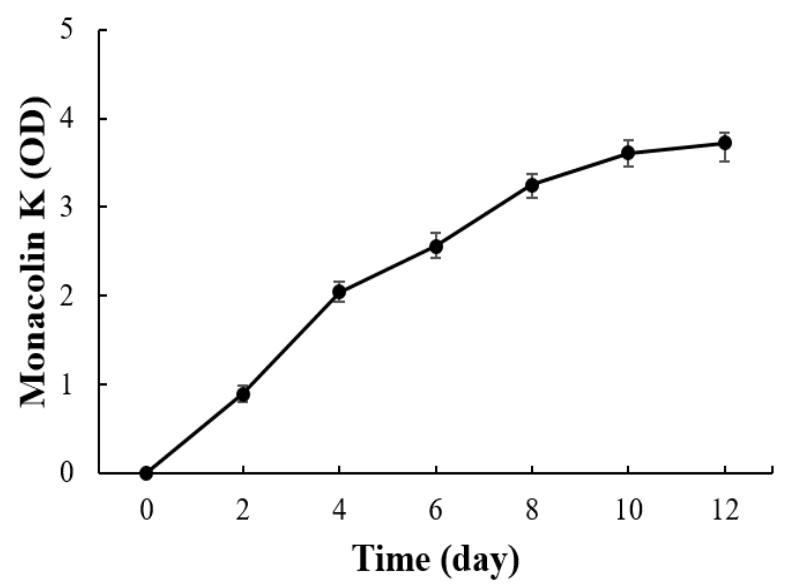

Fig. 3. Changes in monacolin $\mathrm{K}$ during manufacturing of red rice with Monascus purpureus KCCM 60570 at $25^{\circ} \mathrm{C}$ for 12 days. 
다(22,23). Kang 등(24)은 백미와 메밀에 M. ruber ATCC 20657 을 $10 \%(\mathrm{w} / \mathrm{w})$ 접종하여 $25^{\circ} \mathrm{C}$ 에서 10 일간 배양한 결과 Monacolin K의 양이 점차 감소하였는데 이는 메밀의 발아 에 의해 탄소원과 질소원이 감소하였다는 결과와는 차이가 있다. 그러나 Jung 등(18)은 M. purpureus를 사용하여 홍국 을 제조한 결과 monacolin $\mathrm{K}$ 의 양이 3일이 지나면서 급격이 증가하여 15 일경까지 꾸준히 증가하였다는 결과와 유사하 였으며, Ryu 등(25)은 monacolin $\mathrm{K}$ 의 생성량은 $25^{\circ} \mathrm{C}$ 에서 가장 높게 생산되었다고 하여 본 실험에서도 $25^{\circ} \mathrm{C}$ 에서 배양 하였다.

곰팡이수를 측정한 결과는 Fig. 4 와 같으며 홍국쌀 제조 2 일차는 $1.3 \times 10^{1} \mathrm{CFU} / \mathrm{g}, 8$ 일차는 $2.7 \times 10^{4} \mathrm{CFU} / \mathrm{g}$ 으로 홍국 쌀 제조 8 일차까지 곰팡이수가 꾸준히 증가하고 있음을 확인하였고, 이후 완만히 증가하고 있어 홍국쌀 제조는 8 일 정도가 적당한 것으로 나타났다.

이런 결과로부터 M. purpureus KCCM 60570을 이용하여 홍국쌀을 제조할 경우 $25^{\circ} \mathrm{C}$ 에서 8 일 동안 제조하는 것이 가장 적절할 것으로 판단되었다.

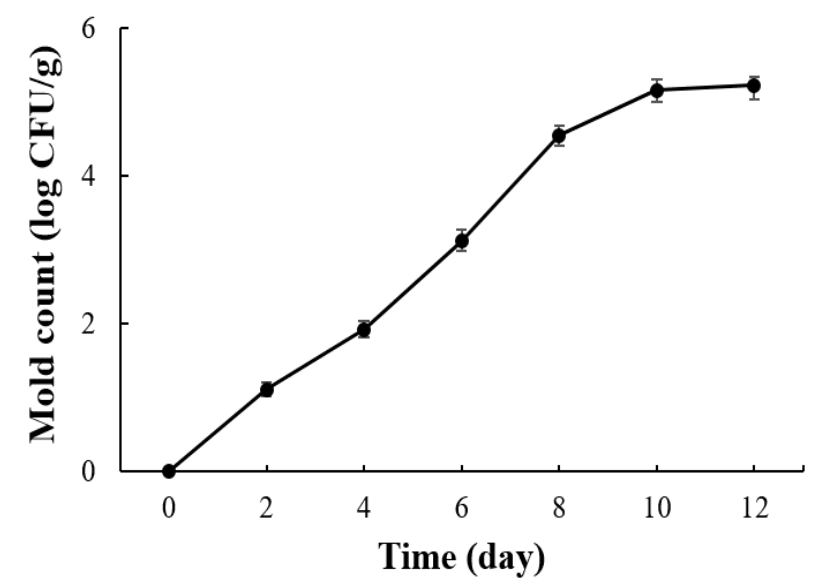

Fig. 4. Changes in mold counts during manufacturing of red rice with Monascus purpureus KCCM 60570 at $25^{\circ} \mathrm{C}$ for 12 days.

\section{홍국쌀의 품질 특성}

홍국쌀의 품질을 확인하기 위해 시중에서 구입한 홍국쌀 2 종, 현미, 백미와 비교한 결과는 Table 2 와 같다. 제조한 홍국쌀의 수분은 $53.71 \%(\mathrm{w} / \mathrm{w})$ 을 보이고 있는데 이는 시중 에서 구입한 홍국쌀의 $14.55 \%, 14.88 \%(\mathrm{w} / \mathrm{w})$, 현미와 백미 의 $14.11 \%, 13.68 \%(\mathrm{w} / \mathrm{w})$ 에 비해 월등히 높은 편으로 이는 본 연구에서는 실험 목적으로 제조한 것이기 때문에 시중에 서 유통 중인 제품들과 차이가 나는 것으로 사료된다.

환원당의 경우 제조한 홍국쌀은 $0.29 \%(\mathrm{w} / \mathrm{w})$ 로 시중에서 구입한 홍국쌀의 $0.20-0.25 \%(\mathrm{w} / \mathrm{w})$ 에 비해 약간 많거나 유 사하였고, 현미 및 백미의 $0.19-0.21 \%(\mathrm{w} / \mathrm{w})$ 보다는 약 1.5 배 많은 편이었다.

제조한 홍국쌀의 조회분량은 $0.35 \%(\mathrm{w} / \mathrm{w})$ 로 다른 시판
홍국쌀, 백미와 유사한 수준이었으며 Lee 등(26)이 일반 백미의 조회분이 $0.4 \%(\mathrm{w} / \mathrm{w})$ 라는 결과와 유사하였다.

monacolin $\mathrm{K}$ 의 흡광도는 제조한 홍국쌀이 3.75 로 시판 홍국쌀의 0.51-0.53보다 약 7배 이상 많은 양이 생성되었으 며 색도는 lightness인 L 값의 경우 제조한 홍국쌀은 35.96으 로 시판 홍국쌀의 57.13-58.68보다 훨씬 낮았고 붉은 색을 나타내는 redness인 a 값은 18.89 로 시판 홍국쌀보다 높게 나타나 monacolin $\mathrm{K}$ 와 비슷한 경향을 보였다.

\section{홍국쌀 첨가 두부 셰이크 관능검사}

Fig. 1 및 Table 1과 같이 홍국쌀을 첨가하여 제조한 4종의 두부 셰이크에 대하여 맛, 향, 색, 조직감 및 전체적인 기호 도에 대하여 30 명의 패널을 이용하여 관능검사를 실시한 결과는 Table 3 과 같다.

맛의 경우 5\% 수준에서 유의성이 인정되어 시료간에 차이가 있는 것으로 나타났으며 홍국쌀을 $0.5 \%(\mathrm{w} / \mathrm{w})$ 를 첨가한 두부 셰이크가 7.50 로 가장 높았고 홍국쌀을 0.7 및 $1.0 \%(\mathrm{w} / \mathrm{w})$ 첨가한 두부 셰이크가 낮은 4.50 와 4.67 으로 낮아 홍국쌀의 첨가량이 많을수록 맛이 떨어지는 것으로 나타났다.

향의 경우 5\% 수준에서 유의성이 인정되지 않아 시료간 에 차이가 없는 것으로 나타났지만 색의 경우 $5 \%$ 수준에서 유의성이 인정되어 시료간에 차이가 있는 것으로 나타났 다. 즉 홍국쌀을 $0.3 \%(\mathrm{w} / \mathrm{w})$ 첨가한 두부 셰이크가 가장 높은 7.50 을 얻은 반면 홍국쌀을 $0.7 \%$ 또는 $1.0 \%(\mathrm{w} / \mathrm{w})$ 첨가한 두부 셰이크가 가장 낮은 4.17 로 홍국쌀의 첨가량이 많을수록 기호도가 떨어지는 것을 확인할 수 있었다.

조직감의 경우 5\% 수준에서 유의성이 인정되어 시료간 에 차이가 있는 것으로 나타났다. 홍국쌀을 $0.5 \%(\mathrm{w} / \mathrm{w})$ 첨가한 두부 셰이크가 7.33 으로 가장 높고, 홍국쌀을 $1.0 \%$ $(\mathrm{w} / \mathrm{w})$ 이상 첨가한 두부 셰이크가 3.50 로 가장 낮아 홍국쌀 의 첨가량이 많을수록 기호도가 저하되는 것으로 나타났 다. 전체적인 기호도의 경우 5\% 수준에서 유의성이 인정되 어 시료간에 차이가 있음을 확인하였고 홍국쌀이 $0.5 \%$ $(\mathrm{w} / \mathrm{w})$ 첨가된 두부 셰이크가 가장 높은 7.33 을 얻었다.

관능적 기호도 검사 결과로부터 기존의 두부 셰이크에 홍국쌀을 $0.5 \%(\mathrm{w} / \mathrm{w})$ 첨가한 것이 기호도가 가장 좋은 것으 로 나타났으며 따라서 홍국쌀의 최적 첨가량은 $0.5 \%(\mathrm{w} / \mathrm{w})$ 가 적당한 것으로 판단되었다.

또한 홍국쌀의 최적 혼합량인 $0.5 \%(\mathrm{w} / \mathrm{w})$ 를 첨가한 셰이 크와 기존 두부 셰이크와의 기호도를 비교하기 위해 맛, 향, 색, 조직감 및 전체적인 기호도에 대하여 30 명의 패널을 이용하여 실시한 관능검사 결과는 Table 4 와 같다.

전체적인 기호도의 경우 $5 \%$ 수준에서 유의성이 인정되 지 않아 두 시료간의 차이가 없음을 알 수 있었다. 다만 맛, 향, 색 및 조직감의 경우 $5 \%$ 수준에서 유의성이 인정되 어 두 시료간에 차이가 있음을 알 수 있었다. 즉 맛은 기존 
Table 2. The physicochemical components of red rice, brown rice and milled rice

(unit: \%)

\begin{tabular}{|c|c|c|c|c|c|c|}
\hline \multirow{2}{*}{\multicolumn{2}{|c|}{ Parameters }} & \multicolumn{5}{|c|}{ Sample } \\
\hline & & Red rice ${ }^{1)}$ & Red rice- $\mathrm{A}^{2)}$ & Red rice- $\mathrm{B}^{2)}$ & Brown rice & Milled rice \\
\hline \multicolumn{2}{|c|}{ Moisture } & $53.71 \pm 1.60$ & $14.55 \pm 0.25$ & $14.88 \pm 0.13$ & $14.11 \pm 0.09$ & $13.68 \pm 0.05$ \\
\hline \multicolumn{2}{|c|}{ Reducing sugar ${ }^{3)}$} & $0.29 \pm 0.01$ & $0.25 \pm 0.03$ & $0.20 \pm 0.03$ & $0.21 \pm 0.01$ & $0.19 \pm 0.02$ \\
\hline \multicolumn{2}{|c|}{ Crude ash ${ }^{3)}$} & $0.35 \pm 0.01$ & $0.32 \pm 0.03$ & $0.34 \pm 0.02$ & $1.32 \pm 0.02$ & $0.36 \pm 0.02$ \\
\hline \multicolumn{2}{|c|}{$\begin{array}{l}\text { Monacolin K } \\
\text { (OD) }\end{array}$} & $3.75 \pm 0.14$ & $0.53 \pm 0.06$ & $0.51 \pm 0.01$ & - & - \\
\hline \multirow{3}{*}{ Color } & $\mathrm{L}$ & 35.96 & 57.13 & 58.68 & 68.82 & 85.63 \\
\hline & a & 18.89 & 12.99 & 15.60 & 2.61 & 0.06 \\
\hline & $\mathrm{b}$ & 9.48 & 8.99 & 10.31 & 14.58 & 8.08 \\
\hline
\end{tabular}

${ }^{1)}$ Red rice was manufactured with Monascus purpureus KCCM 60570 at $25^{\circ} \mathrm{C}$ for 8 days.

${ }^{2)}$ Red rices were purchased in the market.

${ }^{3)}$ Each value was represented with anhydride.

Table 3. Sensory evaluation ${ }^{1)}$ of shake added with different amount of red rice manufactured with Monascus purpureus KCCM 60570

\begin{tabular}{ccccc}
\hline \multirow{2}{*}{ Parameters } & \multicolumn{4}{c}{ Sample $^{2)}$} \\
\cline { 2 - 5 } & $\mathrm{A}$ & $\mathrm{B}$ & $\mathrm{C}$ & $\mathrm{D}$ \\
\hline Taste & $6.50 \pm 1.52^{\mathrm{b} 3)}$ & $7.50 \pm 1.23^{\mathrm{a}}$ & $4.50 \pm 0.85^{\mathrm{c}}$ & $4.67 \pm 0.83^{\mathrm{c}}$ \\
Flavor & $7.17 \pm 0.97^{\mathrm{a}}$ & $7.50 \pm 0.85^{\mathrm{a}}$ & $7.20 \pm 1.47^{\mathrm{a}}$ & $7.50 \pm 1.38^{\mathrm{a}}$ \\
Color & $7.50 \pm 1.38^{\mathrm{a}}$ & $7.17 \pm 0.97^{\mathrm{a}}$ & $4.17 \pm 0.45^{\mathrm{b}}$ & $4.17 \pm 0.45^{\mathrm{b}}$ \\
Texture & $6.17 \pm 0.97^{\mathrm{b}}$ & $7.33 \pm 1.51^{\mathrm{a}}$ & $3.67 \pm 1.19^{\mathrm{c}}$ & $3.50 \pm 1.20^{\mathrm{c}}$ \\
Overall acceptability & $6.50 \pm 0.56^{\mathrm{b}}$ & $7.33 \pm 0.54^{\mathrm{a}}$ & $4.33 \pm 0.54^{\mathrm{c}}$ & $3.67 \pm 0.54^{\mathrm{d}}$ \\
\hline
\end{tabular}

${ }^{1)}$ Each values represented the mean $\pm \mathrm{SD}$ of 30 observations using hedonic scale of 1 (dislike very much) to 9 (like very much).

${ }^{2)}$ Samples were referred to Table 1 .

${ }^{3) a-c}$ Values with different superscripts with the same row are significantly differently at $\mathrm{p}<0.05$.

두부 셰이크가 8.20 을 얻은 반면 $0.5 \%(\mathrm{w} / \mathrm{w})$ 의 홍국쌀을 첨가한 셰이크가 7.60으로 약간 낮은 것을 볼 수 있었다. 이는 홍국쌀의 첨가로 기존 두부 셰이크보다 약간의 맛이 떨어지는 것으로 향후 이에 대한 보완 연구가 필요한 것으 로 나타났다. 향의 경우 기존의 두부 셰이크는 8.00으로 홍국쌀을 첨가한 셰이크의 6.70 보다 높은 반면 색은 오히려 홍국쌀을 첨가한 셰이크가 7.80으로 기존의 두부 셰이크의 6.57보다 높은 점수를 얻었다. 조직감은 기존의 두부 셰이 크의 6.60보다 홍국쌀을 첨가한 셰이크가 8.00으로 나타났 는데 이는 홍국쌀의 첨가로 맛의 부드러움을 느낄 수 있어 높은 점수를 얻은 것으로 사료된다.

이와 같이 기존의 두부 셰이크에 홍국쌀을 첨가하였을 경우 색과 조직감에서 좋은 기호도를 얻어 홍국쌀 첨가 두부 셰이크의 제품화 및 상품화의 가능성을 볼 수 있는 반면 맛과 향이 기존의 두부 셰이크에 비해 떨어지는 것으 로 나타나 향후 이에 대한 보완 연구가 필요한 것으로 나타 났다.
Table 4. Sensory evaluation ${ }^{1)}$ of tofu shake and shake added with red rice manufactured with Monascus purpureus KCCM 60570

\begin{tabular}{ccc}
\hline \multirow{2}{*}{ Parameters } & \multicolumn{2}{c}{ Sample $^{2)}$} \\
\cline { 2 - 3 } & Tofu shake (control) & Sample-B \\
\hline Taste & $8.20 \pm 1.28^{\mathrm{a} 3)}$ & $7.60 \pm 1.20^{\mathrm{b}}$ \\
Flavor & $8.00 \pm 0.82^{\mathrm{a}}$ & $6.70 \pm 1.77^{\mathrm{b}}$ \\
Color & $6.57 \pm 1.91^{\mathrm{b}}$ & $7.80 \pm 0.79^{\mathrm{a}}$ \\
Texture & $6.60 \pm 1.14^{\mathrm{b}}$ & $8.00 \pm 0.68^{\mathrm{a}}$ \\
Overall acceptability & $7.80 \pm 1.11^{\mathrm{a}}$ & $7.50 \pm 1.23^{\mathrm{a}}$ \\
\hline
\end{tabular}

${ }^{1)}$ Each values represented the mean $\pm \mathrm{SD}$ of 30 observations using hedonic scale of 1 (dislike very much) to 9 (like very much).

${ }^{2)}$ Control and sample-B were referred to Table 1 .

${ }^{3 \text { 3a-b }}$ Values with different superscripts with the same row are significantly differently at $\mathrm{p}<0.05$.

\section{홍국쌀 첨가 두부 셰이크의 품질 특성}

M. purpureus KCCM 60570으로 제조한 홍국쌀 첨가 셰 이크와 기존의 두부 셰이크와의 품질을 비교하기 위해 일반 성분 분석과 미생물 분석 결과는 Table 5 와 같다.

수분의 경우 기존의 두부 셰이크와 홍국쌀 첨가 셰이크 는 각각 $82.82 \%(\mathrm{w} / \mathrm{w})$ 와 $82.42 \%$ 로 두 시료가 유사한 정도를 보이고 있으며, 조단백질의 경우도 각각 $4.35 \%$ 와 $4.64 \%$ (w/w)로 유사하였다. 환원당은 기존의 두부 셰이크는 $0.23 \%(\mathrm{w} / \mathrm{w})$ 인 것에 반해 홍국쌀을 첨가한 셰이크는 $1.74 \%$ $(\mathrm{w} / \mathrm{w})$ 로 7 배 이상 높은 편이었고 총당, 조회분 역시 홍국쌀 을 첨가한 셰이크가 다소 높았다.

붉은 색을 나타내는 monacolin $\mathrm{K}$ 는 기존의 두부 셰이크 에서는 검출되지 않았지만 홍국쌀이 첨가된 셰이크에서 붉은 색을 띠고 있어 흡광도가 0.027 을 나타내었다. 색도의 경우 밝은 색인 L 값은 기존의 두부 셰이크가 약간 높은 값을 나타내고 있으나 붉은 정도를 나타내는 a 값은 홍국쌀 을 첨가한 셰이크가 두부 셰이크에 비해 월등히 높은 값을 
나타내어 monacolon $\mathrm{K}$ 의 값과 유사한 결과를 보여주고 있 었다.

두 제품의 위생 상태를 알아보기 위해 일반 세균수, 대장 균 및 대장균군을 분석한 결과 균이 검출되지 않아 위생적 으로 제조된 것을 알 수 있었고 또한 살균조건이 적합한 것으로 나타났다.

이상의 결과로부터 기존의 두부 셰이크에 홍국쌀을 첨가 하여 제조할 경우 품질이 개선된 셰이크의 제조 가능성을 볼 수 있었고 위생적으로도 안전한 제품을 제조할 수 있는 제조기술을 확보할 수 있었다.

Table 5. The physicochemical and microbiological analysis of tofu shake and shake added with red rice manufactured with Monascus purpureus KCCM 60570

\begin{tabular}{|c|c|c|c|}
\hline \multirow{2}{*}{\multicolumn{2}{|c|}{ Parameters }} & \multicolumn{2}{|l|}{ Sample $^{1)}$} \\
\hline & & Tofu shake (control) & Sample-B \\
\hline \multicolumn{2}{|r|}{ Moisure } & $82.82 \pm 0.02$ & $82.42 \pm 0.69$ \\
\hline \multicolumn{2}{|r|}{ Crude protein ${ }^{2}$} & $4.35 \pm 0.04$ & $4.64 \pm 0.03$ \\
\hline \multicolumn{2}{|r|}{ Reducing sugar $\left.{ }^{2}\right)$} & $0.23 \pm 0.01$ & $1.74 \pm 0.03$ \\
\hline \multicolumn{2}{|r|}{ Total sugar ${ }^{2)}$} & $6.82 \pm 0.42$ & $7.82 \pm 0.47$ \\
\hline \multicolumn{2}{|r|}{ Crude fat ${ }^{2}$} & $3.34 \pm 0.15$ & $2.98 \pm 0.01$ \\
\hline \multicolumn{2}{|r|}{ Crude ash $^{2)}$} & $0.82 \pm 0.02$ & $0.89 \pm 0.01$ \\
\hline \multicolumn{2}{|c|}{ Monacolin K (OD) } & - & $0.027 \pm 0.01$ \\
\hline \multirow{3}{*}{\multicolumn{2}{|c|}{ Color }} & 68.48 & 59.24 \\
\hline & & -1.64 & 23.46 \\
\hline & & 6.83 & 9.46 \\
\hline \multicolumn{2}{|c|}{ Viable cell count (CFU/g) } & $\mathrm{ND}^{3)}$ & $\mathrm{ND}$ \\
\hline \multicolumn{2}{|c|}{ E. coli count $(\mathrm{CFU} / \mathrm{g})$} & ND & ND \\
\hline The number & of coli-form group (MPN) & ND & ND \\
\hline
\end{tabular}

${ }^{1)}$ Control and sample-B were referred to Table 1 .

${ }^{2)}$ Each value was represented with anhydride.

${ }^{3)} \mathrm{ND}$, not detected.

\section{요 약}

본 연구에서는 홍국쌀에서 분리한 M. purpureus $\mathrm{KCCM}$ 60570 을 찐 쌀에 $1.0 \%(\mathrm{w} / \mathrm{w})$ 접종 후 $25^{\circ} \mathrm{C}$ 에서 배양하면서 홍국쌀 제조 조건 확립 및 품질 특성을 확인하였다. 또한 기존의 두부 셰이크에 홍국쌀을 첨가한 두부 셰이크의 기호 도 조사를 통해 적정한 혼합비율을 결정하고, 품질 특성을 확인하였다. M. purpureus KCCM 60570으로 제조한 홍국 쌀의 monacolin $\mathrm{K}$ 와 곰팡이수를 확인한 결과 배양 8 일차까 지 급격히 증가하다가 이후 완만히 증가하여 홍국쌀의 적정 제조온도 및 시간은 $25^{\circ} \mathrm{C}$ 에서 8 일로 나타났다. 기존의 두부 셰이크에 M. purpureus $\mathrm{KCCM} 6057$ 으로 $25^{\circ} \mathrm{C}$ 에서 8 일간
제조한 홍국쌀을 서로 다른 농도로 첨가한 두부 셰이크의 관능검사 결과 맛, 향, 조직감 및 전체적인 기호도에서 $0.5 \%$ $(\mathrm{w} / \mathrm{w})$ 홍국쌀을 첨가한 두부 셰이크의 기호도가 가장 높은 것으로 나타나 두부 셰이크의 적정 홍국쌀 혼합 비율은 $0.5 \%(\mathrm{w} / \mathrm{w})$ 인 것으로 나타났다. 홍국쌀을 $0.5 \%(\mathrm{w} / \mathrm{w})$ 첨가 한 두부 셰이크와 기존 시판 두부 셰이크의 품질 특성을 비교한 결과 홍국쌀 첨가 두부 셰이크의 환원당과 총당 함량, 붉은 색소인 monacolin $\mathrm{K}$ 와 색도 a 값이 월등히 높은 것으로 나타났다. 또한 기존 두부 셰이크와 $0.5 \%(\mathrm{w} / \mathrm{w})$ 홍국쌀을 첨가한 두부 셰이크와의 관능검사를 비교한 결과 색과 조직감이 좋은 것으로 나타나 두부 셰이크 제조에 홍국쌀을 첨가할 경우 두부 셰이크의 품질을 개선할 수 있는 가능성을 확인할 수 있었다.

\section{감사의 글}

본 연구는 중소기업청에서 지원하는 2014년도 산학연협 력기술개발사업(No. C0272550)에 의하여 수행된 연구 결 과물의 일부이며, 이에 감사드립니다.

\section{References}

1. Kwon CS (2014) Effect of red yeast (Monascus purpureus) rice supplemented diet on lipid profiles and antioxidant activity in hypercholesterolemic rats. J Korean Soc Food Sci Nutr, 43, 16-23

2. Ma J, Li Y, Ye Q, Li J, Hua Y, Ju D, Zhang D, Cooper R, Chang M (2000) Constituents of red yeast rice, a traditional chinese food and medicine. J Agric Food Chem, 48, 5220-5225

3. Aniya $\mathrm{Y}$, Ohtani II, Higa $\mathrm{T}$, Miyagi $\mathrm{C}$, Gibo $\mathrm{H}$, Shimabukuro M, Nakanishi H, Taira J (2000) Dimerumic acid as an antioxidant of the mold, Monascus anka. Free Radical Biol Med, 28. 999-1004

4. Wu G, Wu X (2000) Screening DPPH radical scavengers from Monascus sp.. Acta Microbiol Sin, 40, 394-399

5. Wang J, Lu Z, Chi J, Wang W, Su M, Kou W, Yu P, Yu L, Chen L, Zhu JS, Chang J (1997) Multicenter clinical trial of the serum lipid-lowering effects of a Monascus purpureus rice preparation from traditional chinese medicine. Curr Ther Res, 58, 964-978

6. Li C, Zhu Y, Wang Y, Zhu JS, Chang J, Kritchevsky D (1998) Monascus purpureus fermentation rice : a natural food product that lowers blood cholesterol in animal models of hypercholesterolemia. Nutr Res, 18, 
71-81

7. Heber D, Yip I, Ashley JM, Elashoff DA (1999) Cholesterol-lowering effects of a proprietary chinese red-yeast-rice dietary supplement. Am J Clin Nutr. 69, 231-236

8. Su YC, Wang JJ, Lin TT, Pan TM (2003) Production of the secondary metabolites gamma-aminobutyric acid and monacolin $\mathrm{K}$ by Monascus. J Ind Microbiol Biotechnol, 30, 41-46

9. Kwon DJ, Lee JE, Kwon SY, Lee SS, Cho EJ (2015) Quality improvement of soybean curd shake and diversification of shake products. Final Report of AURI, AURI 15-C0272550

10. Kim DW (2013) Quality characteristics of sausage added red yeast rice. Korean J Food Preserv, 20, 805-809

11. Kwon CS (2012) Antioxidant properties of red yeast rice(Monascus purpureus) extracts. J Korean Soc Food Sci Nutr, 41, 437-442

12. Kim NS, Lee KT (2007) Physiochemical properties of functional oils produced using red yeast-rice ethanol extracts and diacylglycerol oil. J Korean Soc Food Sci Nutr, 36, 201-208

13. AOAC (1995) Official Method of Analysis. $16^{\text {th }}$ ed, Association of official analytical communities, Arlington, VA, USA, method 925.10, p 1

14. Somogyi M (1927) Notes on sugar determination. J Biol Chem, 195, 19-23

15. AOAC (1995) Official Method of Analysis. $16^{\text {th }}$ ed, Association of official analytical communities, Arlington, VA, USA, method 923.03, p 2

16. AOAC (1995) Official Method of Analysis. $16^{\text {th }} \mathrm{ed}$, Association of official analytical communities, Arlington, VA, USA, method 920.87, p 12
17. AOAC (1995) Official Method of Analysis. $16^{\text {th }}$ ed, Association of official analytical communities, Arlington, VA, USA, method 920.85, p 5

18. Jung HJ, Yoo DS (2004) Production of monascolin K by Monascus sp. in solid culture. Korean J Microbiol, 40, 160-166

19. Kim DY, Kwon DJ (2014) Quality characteristics of Doenjang manufactured with soybean Koji. Korean J Food Reserv, 21, 434-441

20. Difco Manual (1984) Difco laboratories. $19^{\text {th }}$ ed, Detroit, MI, USA, p 689 (PDA), p 679 (PCA)

21. Kwon DJ (2009) Food microbiology and experiment, Shinkwang Publishing Co, Seoul, Korea, p 172-180

22. Endo A (1980) Monacolin K, a new hypocholesterolemic agent that specifically inhibits 3-hydroxy-3-methylglutaryl coenzyme a reductases. J Antibiotics, 33, 334-336

23. Endo A, Komagata D, Shimada H (1986) Monacolin M, a new inhibitor of cholesterol biosynthesis. J Antibiot, 39, 1670-1673

24. Kang DZ, Um JB, Lee SK, Lee JH (2003) Content of rutin and monacolin $\mathrm{K}$ in the red buckwheat fermented with Monascus ruber. Korean J Food Sci Technol, 35, 242-245

25. Ryu BH, Ahn MK, Park JO (1995) Production of cholesterol inhibitor, Monacolin produces from Monascus pilosus M-15. L Korean Soc Food Nutr, 24, 92-97

26. Lee JH, Kwak EJ, Kim JS, Lee KS, Lee YS (2007) A study on quality characteristics of sourdough breads with addition of red yeast rice. J Korean Soc Food Sci Nutr, 36, 785-793 